\title{
BUSINESS DEVELOPMENT ON TEMANRINDU STARTUP WITH STARTUP EVOLUTION CURVE METHODS
}

\author{
Rasyid Yudhistira ${ }^{*}$, Yuniaristanto ${ }^{2}$, Muhammad Hisjam ${ }^{3}$ \\ 1,2,3 Industrial Engineering Department, Faculty of Engineering, Sebelas Maret University \\ E-mail : rasyidyudh@student.uns.ac.id ${ }^{1}$, yuniaristanto@ft.uns.ac.id ${ }^{2}$, hisjam@staff.uns.ac.id ${ }^{3}$
}

\begin{abstract}
Technological developments have made it easier for people to use social networks. Almost all people of productive age use the internet in their social interactions. The purpose of this research is primarily to provide a platform for TemanRindu to make its product prototype appropriately with the Lean Canvas business model and so Startup Evolution Curve as its method. The main principles of Startup Evolution Curve are providing step-by-step guidance in company discussions, business development of TemanRindu by Feasibility Study especially on market aspect so that shown the segment and position TemanRindu itself. Product prototyping or Minimum Viable Product (MVP) start from doing hypothesis verification that will be used on MVP adjustment. Slogan making and pipe and sales funnel are also be done that lately will be used to planning the marketing strategy. This method has succeeded on generating of TemanRindu's market segmentation and positioning as well as the making of product prototype in the form of Instagram design based on Lean Canvas design. Its affect on increasing of business growth in followers, likes, comments and saves because the product has been more adapted to customer needs without reducing the added value that offered.
\end{abstract}

Keywords : startup, business development, startup evolution curve, MVP, lean canvas

\section{PENGEMBANGAN BISNIS PADA STARTUP TEMANRINDU DENGAN METODE STARTUP EVOLUTION CURVE}

\begin{abstract}
ABSTRAK
Perkembangan teknologi menyebabkan semakin mudahnya masyarakat dalam menggunakan jejaring sosial. Hampir keseluruhan masyarakat usia produktif memakai internet dalam interaksi sosialnya. Tujuan dari penelitian ini adalah menyediakan sarana untuk startup TemanRindu dalam membuat prototipe produk bisnisnya dengan model bisnis Lean Canvas secara tepat dan dengan metode Startup Evolution Curve. Prinsip utama dari Startup Evolution Curve adalah memberikan arahan per tahap dalam diskusi perusahaan, dan pengembangan bisnis startup TemanRindu melalui Feasibility Study pada aspek pasar sehingga memberikan gambaran terhadap segmen dan posisi daripada TemanRindu. Pembuatan prototipe produk atau Minimum Viable Product (MVP) dilakukan dari verifikasi hipotesis yang akan digunakan pada penyesuaian MVP. Pembuatan slogan hingga uji komunikasi dan saluran distribusi juga dilakukan yang kemudian dapat digunakan untuk menentukan strategi pemasaran. Pengaplikasian metode tersebut berhasil menghasilkan pemetaan daripada segmentasi dan posisi TemanRindu di pasar dan juga terciptanya prototipe produk TemanRindu berupa desain kiriman Instagram yang berdasarkan atas rancangan Lean Canvas. Dampaknya pertumbuhan bisnis naik, baik pada followers, likes, comment maupun save karena produk telah lebih disesuaikan dengan kebutuhan pelanggan tanpa mengurangi nilai lebih yang ditawarkan TemanRindu.
\end{abstract}

Kata kunci : startup, pengembangan bisnis, startup evolution curve, MVP, lean canvas

AdBispreneur : Jurnal Pemikiran dan Penelitian Administrasi Bisnis dan Kewirausahaan 


\section{PENDAHULUAN}

Proses eksplorasi pendekatan alternatif untuk kesehatan mental, penting untuk memahami dahulu apa sebenarnya penyakit mental itu. Penyakit mental (mental illness) adalah kondisi-kondisi yang mampu mempengaruhi suasana hati, pemikiran dan tindakan dari seseorang. Skizofrenia, depresi, gangguan kecemasan bahkan perilaku-perilaku yang terkesan adiktif termasuk dalam penyakit mental. Penyakit mental harus diberi perhatian lebih jika tanda dan gejala mempengaruhi atau berpotensi mengganggu keberjalanan hari seseorang tersebut. Penyakit mental bisa saja membuat seseorang sangat menderita dalam menjalani kehidupan sehari-hari, seperti di kampus, lingkungan kantor, rumah atau bahkan dalam suatu hubungan. Gejala biasanya dapat dikendalikan dengan obat dan terapi bicara (psikoterapi). Secara umum, penggolongan gangguan jiwa dapat dibagi menjadi dua, yaitu gangguan jiwa ringan dan gangguan jiwa berat.

Antara lain yang termasuk gangguan jiwa ringan adalah kecemasan (anxiety), depresi, psikosomatis dan kekerasan. Sedangkan yang termasuk dalam gangguan jiwa berat antara lain manik-depresif, skizofrenia dan aditif psikotik lainnya. Hawari (2005), menjelaskan gejala dan tanda gangguan jiwa ringan antara lain adalah perasaan khawatir dan firasat buruk (overthinking), merasa tegang dan gelisah, takut atas kesendirian atau keramaian, gangguan pola tidur dan mimpi-mimpi yang menegangkan, gangguan konsentrasi serta berbagai keluhan somatik seperti nyeri pada otot dan tulang, telinga berdenging, sesak nafas dan sakit kepala. Depresi juga salah satu dari gangguan jiwa ringan yang sangat berbahaya. Gejala dan tanda depresi antara lain rasa sedih yang berkelanjutan, rasa putus asa, rasa bersalah (self blaming), energi lemah, kurang tidur (insomnia) atau tidur berlebihan (hipersomnia), sulit makan atau malah rakus, gampang tersinggung dan kecenderungan untuk mati atau bunuh diri (Gordon, 2018).

Menurut Suryaningrum (2013), gangguan jiwa terjadi karena faktor-faktor yang berinteraksi satu sama lain. Antara lain penyebab gangguan jiwa adalah pengalaman yang traumatis, faktor biologis seperti faktor genetik dan gangguan struktur fungsi otak, faktor neurotransmitter, senyawa organik endogen yang membawa sinyal di antara neuron. Ada juga faktor psiko-edukasi, faktor copping, tekanan psiko-sosial dan pemahaman serta keyakinan pada agama. Menurut Indarjo (2009), di antaranya dapat menyebabkan gangguan jiwa ringan sampai berat. Terlebih kita disajikan kenyataan bahwa masyarakat hanya berfokus untuk mengembangkan kesehatan secara fisik saja, mengesampingkan faktor non-fisik seperti mental emosional dan psikososial.

Interaksi sosial salah satu pemicu gangguan mental. Mengingat bahwa media sosial memungkinkan seluruh pengguna untuk mengeksplorasi identitas diri dan mengekspresikan emosi atau pikiran (James, et. al., 2018). Kita disajikan pula dengan kenyataan bahwa kini seluruh masyarakat pada usia produktif menggunakan internet dan gawai sebagai senjata utamanya dalam berinteraksi sosial. Menurut survei yang dilakukan Asosiasi Penyelenggara Jasa Internet Indonesia (APJII) pada tahun 2017, pengguna internet di Indonesia mencapai angka 143 juta dari jumlah populasi 263 juta atau dikatakan lebih dari setengah menggunakan fasilitas internet untuk bersosialisasi. Sebaran terbanyak berada di Pulau Jawa dengan angka pengguna 80 juta atau $60 \%$ dari pengguna internet. Menurut survei tersebut sebanyak $42,8 \%$ pengguna adalah remaja dengan rentang umur 10-35 tahun. Tetapi, dari data yang menunjukkan banyaknya pengguna internet, tidak semuanya memahami bagaimana cara untuk menjadi sehat mental dan menjadikan media sosial lingkungan yang baik. Internet bukanlah penyebab utama seseorang menjadi gangguan mental, tetapi bisa jadi internet adalah pemicu awal dari seseorang yang belum atau sudah memiliki gejala gangguan mental (James, et. al., 2018). Penggunaan internet yang tidak bijak tercermin pada angka tingkat kelaziman kesehatan jiwa di Indonesia hanya sebesar $18,5 \%$ dan presentase tersebut cenderung meningkat (Indarjo, 2009).

Berangkat dari banyaknya pengguna internet, masyarakat semakin besar kesempatan untuk berinovasi dan mendirikan rintisan perusahaan yang disebut startup. Startup adalah organisasi yang dirancang untuk mencipta

318 AdBispreneur : Jurnal Pemikiran dan Penelitian Administrasi Bisnis dan Kewirausahaan Vol.5, No.3, Desember 2020, DOI : https://doi.org/10.24198/adbispreneur.v5i1.30641, hal.317-331 
produk atau layanan di bawah kondisi yang tidak pasti (Ries, 2011). Menurut Jonikas (2017), bahwa $90 \%$ dari semua startup gagal dan tak bisa menjadi profit. Gagalnya startup dikarenakan kegagalan perusahaan mengelola sumber daya yang terbatas sehingga siklus perputaran uang tidak baik hingga mendapat revenue stream yang tidak memadai di awal keberjalanan (Colis, 2016).

Startup Evolution Curve dipilih sebagai metode dikarenakan metode tersebut memaparkan tiap langkah detail untuk para pengembang startup pemula (Sharfina, 2019). Metode Startup Evolution Curve mengharuskan startup memvalidasi semua aspek sebelum benar-benar dilemparkan ke pasar. Hal tersebut bertujuan untuk menghindari banyaknya perubahan karena sudah pernah melakukan penyelarasan pasar sebelumnya. Startup Evolution Curve memiliki lima tahap pengembangan. Hal tersebut menandakan startup dapat mendefinisikan model bisnis. TemanRindu secara mandiri sudah melakukan feasibility study pada keberjalanannya. Dalam penelitian ini dibahas langkah-langkah pengembangan pada tahap kedua yaitu pembuatan Minimum Viable Product (MVP)/prototype.

Perbedaan penelitian ini dengan penelitan sejenis sebelumnya adalah pada metode yang dipakai. Penelitian Sharfina (2020), menggunakan Business Model Canvas, sedangkan penelitian ini menggunakan Lean Canvas. Berdasarkan latar belakang yang telah dijelaskan, rumusan masalah yang ditetapkan adalah bagaimana pengembangan model bisnis pada startup TemanRindu dengan metodologi Startup Evolution Curve dapat dilakukan. Penelitian bertujuan untuk membuat prototype mengenai produk yang dikeluarkan oleh TemanRindu dengan menggunakan Lean Canvas. Di sisi lain, penelitian ini juga sangat penting untuk dilakukan karena jika startup TemanRindu dapat berkembang, besar harapan hal tersebut mampu menekan angka gangguan mental khususnya di Indonesia. Karena startup TemanRindu menyediakan produk-produk yang mendukung masyarakat Indonesia untuk menjadi sehat mental.

\section{TINJAUAN PUSTAKA}

Kewirausahaan modern sudah lahir dan berkembang sejak tiga puluh tahun yang lalu. Hal tersebut juga makin didorong oleh pasar konsumen internet pada pertengahan tahun 1990-an dan puncaknya yang terjadi pada tahun 2000 dan dikenal sebagai masa dot-com bubble burst (Perkins, et. al., 1999). Di sisi lain perkembangan teknologi informasi juga mengalami peningkatan di tiga dekade terakhir dan mencapai kematangan hingga mampu mempengaruhi tatanan ekonomi gobal (Marmer, et. al., 2011). Dewasa ini, seiring dengan meluasnya penggunaan internet dan perangkat mobile mengantarkan pada maraknya pertumbuhan perusahaan software atau yang disebut startup bubble (Paternoster dkk., 2014)

Startup berada di satu dunia yang sama dengan kewirausahaan yang digambarkan pada rangkaian kegiatan ekonomi. Startup dapat dikategorikan sebagai bisnis baru, sedang merintis, dan hijau. Dengan kata lain sebagian besar para startup merupakan bisnis yang baru didirikan dan berada pada fase pengembangan dalam menemukan pasar yang sesuai dengan lingkupnya. Menurut Steve Blank (2012), istilah startup lebih dekat dengan perusahaan teknologi dikarenakan banyaknya perusahaan yang menggunakan platform "dot-com" pada tahun 1998.

Tabel 1. Tinjauan Pustaka

\begin{tabular}{|c|c|c|c|}
\hline No & Penulis & Judul & Tahun \\
\hline 1 & $\begin{array}{l}\text { Antonio Ghezzi, } \\
\text { Angelo Cavallo }\end{array}$ & $\begin{array}{l}\text { Agile Business Model } \\
\text { Inovation in Digital } \\
\text { Entrepreneurship: Lean } \\
\text { Startup Approches }\end{array}$ & 2018 \\
\hline 2 & $\begin{array}{l}\text { Nancy Bocken, } \\
\text { Yuliya Snihur }\end{array}$ & $\begin{array}{l}\text { Lean Startup and the } \\
\text { Business Model: } \\
\text { Experimenting for Novelty } \\
\text { and Impact }\end{array}$ & 2019 \\
\hline 3 & $\begin{array}{l}\text { Anders } \\
\text { Gustafsson, Jonas } \\
\text { Qvillberg }\end{array}$ & $\begin{array}{l}\text { Implementing Lean Startup } \\
\text { Methodology }\end{array}$ & 2016 \\
\hline 4 & $\begin{array}{l}\text { Michael Dwianto } \\
\text { Nirwan }\end{array}$ & $\begin{array}{l}\text { Barriers in Implementing } \\
\text { the Lean Startup } \\
\text { Methodology in Indonesia- } \\
\text { Case Study of B2B Startup }\end{array}$ & 2014 \\
\hline 5 & $\begin{array}{l}\text { Nurina Sharfina, } \\
\text { Yuniaristanto, } \\
\text { Roni Zakaria }\end{array}$ & $\begin{array}{l}\text { Business Development on } \\
\text { Bukasuara Startup With } \\
\text { Startup Evolution Curve } \\
\text { Methods }\end{array}$ & 2019 \\
\hline
\end{tabular}




\begin{tabular}{|l|l|l|c|}
\hline No & \multicolumn{1}{|c|}{ Penulis } & \multicolumn{1}{|c|}{ Judul } & Tahun \\
\hline 6 & $\begin{array}{l}\text { Irina Atvoka, } \\
\text { Petri Ahokangas }\end{array}$ & $\begin{array}{l}\text { From Structure to } \\
\text { Proccess: Dynamic Aspect } \\
\text { of Business Model Change }\end{array}$ & 2020 \\
\hline 7 & Julio E. Cuc & $\begin{array}{l}\text { Trends in Business Model } \\
\text { Research: A Bibliometric } \\
\text { Analysis }\end{array}$ & 2019 \\
\hline 8 & $\begin{array}{l}\text { Marco } \\
\text { Montemari, } \\
\text { Maria Serena } \\
\text { Chiucchi, } \\
\text { Christian Nielsen }\end{array}$ & $\begin{array}{l}\text { Designing Performance } \\
\text { Meaurement System Using }\end{array}$ & 2019 \\
\hline 9 & $\begin{array}{l}\text { Yariv Taran, } \\
\text { Rene Chester } \\
\text { Goduscheit, } \\
\text { Harry Boer }\end{array}$ & $\begin{array}{l}\text { Business Model Inovation - } \\
\text { A Gamble or a } \\
\text { Manageable Proccess? }\end{array}$ & 2019 \\
\hline 10 & Krista Sorri & $\begin{array}{l}\text { Business Model Innovation } \\
\text { with Platform Canvas }\end{array}$ & 2019 \\
\hline
\end{tabular}

Kami menemukan bahwa pendekatan teori kompleksitas menekankan sifat multidimensi dari model bisnis yang memungkinkan untuk memahami dinamikan evolusi model bisnis dengan melihat level-level yang berbeda, dari sepuluh penelitian yang dijadikan literatur. Selain itu, dari banyaknya perspektif juga mengungkapkan bahwa dinamika evolusi model bisnis didasarkan pada proses yang berbedabeda (Atvoka, et. al., 2020). Setiap proses inovasi model bisnis melibatkan tingkat ketidakpastian, kompleksitas, dan risiko yang sebenarnya. Pendekatan yang ceroboh terhadap manajemen risiko dapat mengakibatkan bencana, bahkan terkadang fatal, konsekuensi terhadap inti bisnis suatu perusahaan (Taran, et. al., 2020).

Sebuah startup selalu memiliki model bisnis. Model bisnis yang biasa digunakan beragam jenisnya seperti Business Model Canvas (BMC), Lean Canvas, SWOT, Business Model Zen Canvas. Literatur tentang model bisnis berkembang dalam berbagai bidang seperti strategi, inovasi, penciptaan nilai, sistem informasi, teori organisasi, pemasaran, ekonomi, keberlanjutan, kewirausahaan, dll. Topik tersebut dianggap berada dalam fase pengembangan dan konsolidasi mengenai konseptualisasi, tipologi, kerangka kerja, aplikasi, dan pengembangan teori berkelanjutan di lapangan (E. Julio,2019). Business Model Canvas adalah salah satu model bisnis yang sering dipakai karena menggambarkan dasar pemikiran tentang bagaimana organisasi memberikan dan menanggapi nilai yang dipunya (Osterwalder, 2010). Sedangkan model yang kini mulai sering digunakan adalah Lean Canvas. Lean Canvas adalah adaptasi dari Business Model Canvas Model (BMC) yang diciptakan oleh Ash Maurya.

Tingginya kompetisi di persaingan bisnis global memaksa perusahaan untuk memperbaharui model bisnis dengan lebih sering. Oleh karena itu, manajer dan praktisi membutuhkan alat yang dapat mendukung mereka untuk menjawab tantangan tersebut (Montemari, dkk., 2019). Posisi penelitian ini berporos pada penelitian Nurina S. (2019) tetapi memiliki pembeda pada alat atau kanvas yang digunakan yaitu Lean Canvas. Startup yang memakai lean canvas dalam model bisnisnya cenderung bersifat cepat, ringkas dan efektif karena membawa semangat lean (perampingan). Canvas tersebut berfokus pada rencana bisnis yang dapat ditindak lanjut dan problem-finding serta problem-solving dengan penekan terhadap nilai yang dimiliki oleh perusahaan (Maurya, 2010). Salah satu startup yang menggunakan lean canvas adalah TemanRindu.

Tujuan dari sebuah platform adalah untuk memfasilitasi pertukaran produk multi-pihak, yang dapat berupa barang, jasa, atau bahkan mata uang sosial, menciptakan nilai baru dan pada saat yang sama memungkinkan penangkapan nilai. Platform juga dapat dianggap sebagai perantara yang menyatukan anggota dari berbagai kelompok (Sorri K, dkk., 2019). TemanRindu sebagai platform media yang memberikan layanan dan menyajikan informasi melalui media online, salah satu dari proses bisnis utamanya ialah pemberian konten yang menarik, baik dalam bentuk teks edukasi, ilustrasi ataupun video. TemanRindu dipilih untuk menjadi objek penelitian karena dilihat dari perhatian masyarakat terhadap kesehatan jiwa dan peluang bisnis dari startup di bidang manusia yang mengalami kenaikan. Juga karena ide produk yang diusung oleh TemanRindu belum tentu memenuhi kebutuhan pasar. Untuk menciptakan produk yang memenuhi kebutuhan konsumen, penggalangan dana, dan peluncuran 
produk yang cocok diperlukan sebuah metodologi dalam perkembangan startup ini.

Tujuan umum dari Startup Evolution Curve, metode yang dipakai di penelitian ini adalah untuk memeriksa apakah startup telah bekerja dengan baik dan apa yang akan dilakukan oleh para founder dalam usaha berikutnya. Survei ini dijalankan untuk penelitian statistik kuantitatif, sedangkan wawancara mendalam dan studi kasus digunakan untuk analisis kualitatif (Castro, et. al., 2010; Johnson, et. al., 2007). Studi ini telah menyiapkan survei berdasarkan lima tahap pengembangan startup dan telah memasukkan metodologi dan konsep yang direkomendasikan oleh literatur teoritis dan oleh para ahli pengembangan startup yang terkenal.

Jonikas (2017) mengatakan bahwa klasifikasi tahap pengembangan startup masih tetap rumit dan ambigu karena tidak setiap startup dapat dengan jelas mengatakan di mana tahap pengembangan mereka. Oleh karena itu, survei memiliki lima pertanyaan deskriptif untuk pendiri startup untuk menilai sendiri pada skala dari satu hingga sepuluh seberapa dekat mereka antara satu ke benchmark lain. Ini memungkinkan untuk mengidentifikasi tahap pengembangan setiap startup dan untuk memeriksa apakah mereka tahu dan menggunakan metodologi yang direkomendasikan untuk setiap tahap tertentu.

Metode yang digunakan dalam penelitian ini, menggunakan Lean Canvas. Lean Canvas menurut Maurya (2010) adalah sebuah alat yang digunakan untuk menguji hipotes sekaligus untuk melakukan validasi terhadap suatu perusahaan. Lean Canvas juga menjadi alat untuk mendokumentasikan model bisnis, mengukur kemajuan dan pengkomunikasian proses pembelajaran dengan pemangku kepentingan eksternal maupun internal perusahaan.

Lean Canvas mempunyai 9 building blocks didalamnya, yang terdiri dari Problem, Unique Value Proportion, Solution, Channels, Cost Structure, Revenue Streams, Key Metrics, Customer Segments dan Unfair Advantage. Lean Canvas dapat mengetahui hipotesa yang paling mungkin karena rencana dibuat berdasar atas keadaan sekarang dan dibuat tiap segmennya.

Gambar 1. Lean Canvas Template

\begin{tabular}{|l|l|l|l|l|}
\hline Problem & Solution & $\begin{array}{l}\text { Unique Value } \\
\text { Proposition }\end{array}$ & $\begin{array}{c}\text { Unfair } \\
\text { Advantage }\end{array}$ & $\begin{array}{l}\text { Customer } \\
\text { Segments }\end{array}$ \\
\hline & \multicolumn{2}{|l|}{} \\
\hline Key Metrics & \multicolumn{2}{|l|}{ Channels } \\
\hline Cost Structure & Revenue Structure \\
\hline
\end{tabular}

Sumber : Maurya, A. (2010). Running Lean:Iterate From Plan A to A Plan That Works.

\section{METODE PENELITIAN}

Tujuan umum penelitian ini adalah untuk membuat prototype mengenai produk yang dikeluarkan oleh TemanRindu dengan menggunakan Lean Canvas. Studi ini telah menyiapkan survei berdasarkan lima tahap pengembangan startup dan telah memasukkan metodologi dan konsep yang direkomendasikan oleh literatur secara teoritis dan oleh para ahli pengembangan startup terkenal (Jonikas, 2017). 


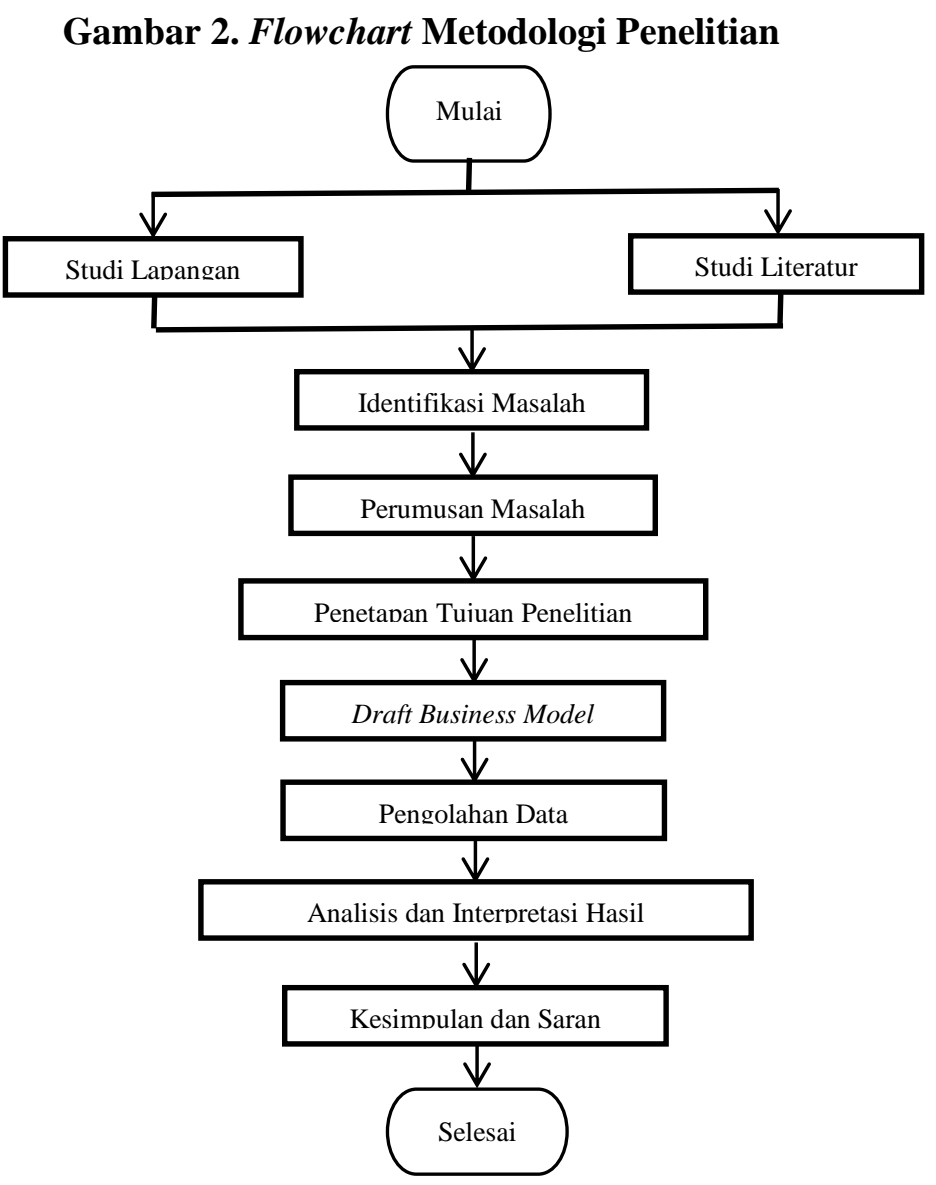

Wawancara mendalam dilakukan untuk mengetahui situasi perusahaan yang lebih dalam. Hal tersebut dilakukan untuk menganalisa metodologi tersebut berkontribusi terhadap perusahaan startup. Startup Evolution Curve membuat TemanRindu tetap fokus dalam

penciptaan bisnis yang menguntungkan dan terukur. Metode tersebut pun dapat diterapkan pada bisnis yang lain seperti bisnis offline, jasa atau ritel, B2C atau B2B. Berikut adalah Startup Evolution Curve oleh Jonikas:

\section{Gambar 3. Tahapan Startup Evolution Curve}

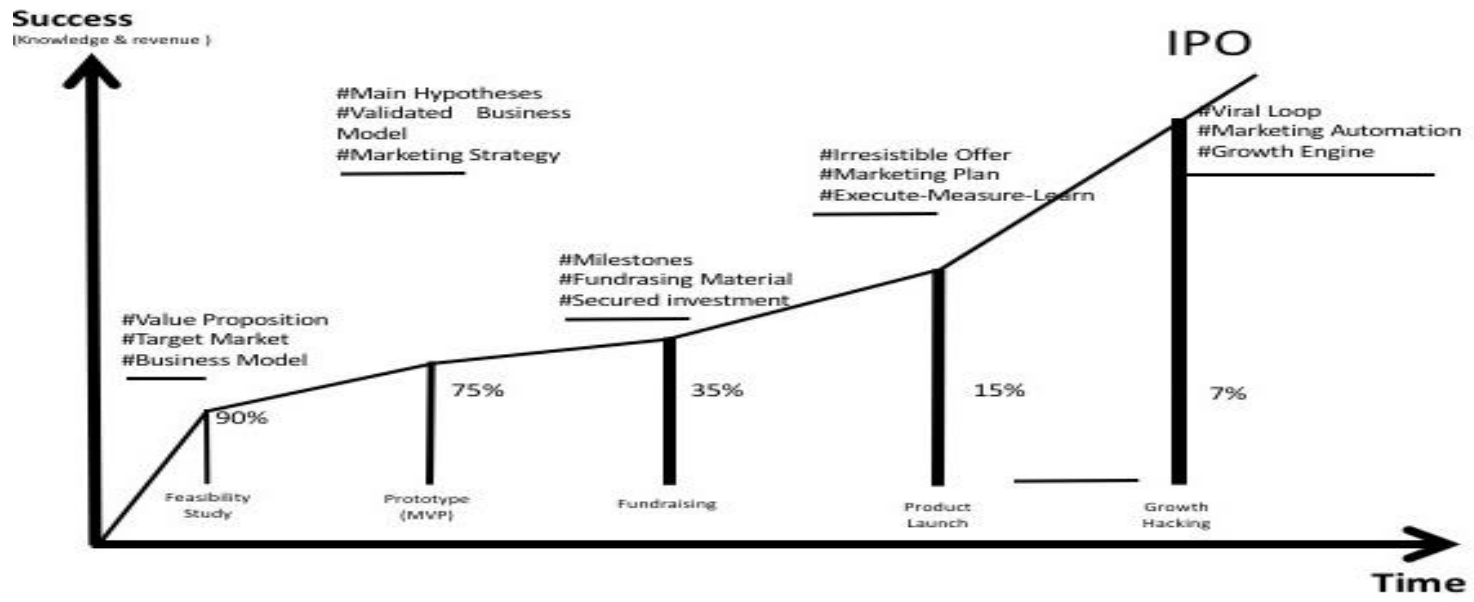

Sumber : Jonikas, D. (2017). Startup Evolution Curve From Idea to Profitable Business Idea

322 AdBispreneur : Jurnal Pemikiran dan Penelitian Administrasi Bisnis dan Kewirausahaan Vol.5, No.3, Desember 2020, DOI : https://doi.org/10.24198/adbispreneur.v5i1.30641, hal.317-331 


\section{Gambar 4. Flowchart Pengolahan Data}

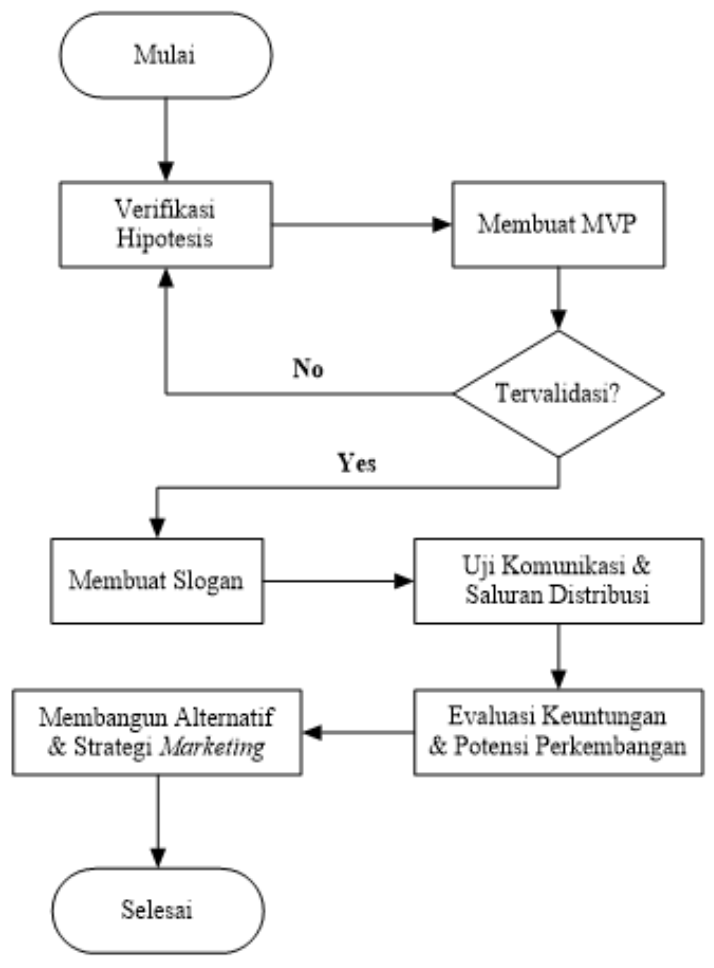

Sumber : Arsip TemanRindu 2020

\section{HASIL DAN PEMBAHASAN}

Penggunaan metode dalam penelitian ini dimulai dari penetapan segmentasi pasar dari perusahaan dikarenakan perusahaan sudah melakukan sebagian feasibility study secara mandiri. Segmentasi pasar berfungsi untuk mengetahui siapa saja yang berpotensi untuk menjadi pelanggan ataupun mitra dari TemanRindu.

\section{Tabel 2. Segmentasi TemanRindu}

\begin{tabular}{|c|c|c|}
\hline Kategori & Customer Market & $\begin{array}{c}\text { Business \& Organization } \\
\text { Market }\end{array}$ \\
\hline \multirow{3}{*}{$\begin{array}{c}\text { Segmentasi } \\
\text { Geografi }\end{array}$} & \multirow{3}{*}{ Masyarakat Indonesia } & $\begin{array}{l}\text { Instansi Medis di Solo dan } \\
\text { sekitarnya }\end{array}$ \\
\hline & & Komunitas di Indonesia \\
\hline & & Perusahaan di Indonesia \\
\hline \multirow{4}{*}{$\begin{array}{l}\text { Segmentasi } \\
\text { Demografi }\end{array}$} & Pria dan Wanita & $\begin{array}{l}\text { Perusahaan yang memiliki } \\
\text { karyawan usia produktif }\end{array}$ \\
\hline & Pelajar dan Mahasiswa & $\begin{array}{l}\text { Perusahaan baru maupun } \\
\text { yang sudah lama }\end{array}$ \\
\hline & $\begin{array}{l}\text { Pekerja dan } \\
\text { pengangguran }\end{array}$ & \multirow{2}{*}{$\begin{array}{l}\text { Instansi pendidikan } \\
\text { menengah atas atau } \\
\text { perguruan tinggi }\end{array}$} \\
\hline & $\begin{array}{l}\text { Usia produktif (18-30 } \\
\text { tahun) }\end{array}$ & \\
\hline
\end{tabular}

\begin{tabular}{|c|c|c|}
\hline Kategori & Customer Market & $\begin{array}{c}\text { Business \& Organization } \\
\text { Market }\end{array}$ \\
\hline \multirow{4}{*}{$\begin{array}{c}\text { Segmentasi } \\
\text { Tingkah } \\
\text { Laku }\end{array}$} & $\begin{array}{l}\text { Masyarakat yang } \\
\text { menghabiskan banyak } \\
\text { waktu di sosial media }\end{array}$ & $\begin{array}{l}\text { Instansi medis atau rumah } \\
\text { sakit jiwa }\end{array}$ \\
\hline & $\begin{array}{l}\text { Masyarakat yang } \\
\text { mencari media } \\
\text { konseling yang instan }\end{array}$ & Perusahaan pemasaran \\
\hline & $\begin{array}{l}\text { Masyarakat yang } \\
\text { merasa kesulitan untuk } \\
\text { membagikan cerita }\end{array}$ & \multirow{2}{*}{ Mitra Psikolog } \\
\hline & $\begin{array}{l}\text { Masyarakat yang sadar } \\
\text { dan mawas terhadap } \\
\text { kesehatan mental }\end{array}$ & \\
\hline \multirow{3}{*}{$\begin{array}{c}\text { Segmentasi } \\
\text { Psikografi }\end{array}$} & $\begin{array}{l}\text { Orang yang tertarik } \\
\text { dengan tampilan yang } \\
\text { segar dan sederhana }\end{array}$ & $\begin{array}{l}\text { Komunitas mawas } \\
\text { kesehatan mental }\end{array}$ \\
\hline & $\begin{array}{l}\text { Orang Syang mencari } \\
\text { wawasan terhadap } \\
\text { kesehatan mental }\end{array}$ & \multirow{2}{*}{$\begin{array}{l}\text { Event Organizer dan } \\
\text { Buzzer }\end{array}$} \\
\hline & $\begin{array}{l}\text { Orang yang mencari } \\
\text { produk konseling } \\
\text { paling murah dan } \\
\text { mudah }\end{array}$ & \\
\hline
\end{tabular}

Sumber : Arsip TemanRindu 2020

Tabel 3. Target, Posisi dan Perbedaan TemanRindu

\begin{tabular}{|c|c|c|}
\hline Kategori & Customer Market & $\begin{array}{c}\text { Business \& } \\
\text { Organization Market }\end{array}$ \\
\hline \multirow{6}{*}{ Target } & $\begin{array}{l}\text { Orang yang didiagnosa } \\
\text { mengidap penyakit mental }\end{array}$ & Psikolog \\
\hline & $\begin{array}{l}\text { Orang yang memiliki } \\
\text { gejala pada kesehatan } \\
\text { mental }\end{array}$ & $\begin{array}{l}\text { Komunitas atau } \\
\text { organisasi yang } \\
\text { bergerak di bidang yang } \\
\text { sama }\end{array}$ \\
\hline & $\begin{array}{l}\text { Orang yang mawas dan } \\
\text { peduli terhadap kesehatan } \\
\text { mental }\end{array}$ & Instansi kesehatan \\
\hline & $\begin{array}{l}\text { Orang yang merasa tidak } \\
\text { memiliki teman }\end{array}$ & \\
\hline & $\begin{array}{l}\text { Orang yang banyak } \\
\text { menghabiskan waktu } \\
\text { membuka sosial media } \\
\end{array}$ & \\
\hline & $\begin{array}{l}\text { Orang yang suka } \\
\text { mendatangi seminar } \\
\text { kesehatan }\end{array}$ & \\
\hline \multirow{5}{*}{ Posisi } & Media katarsis & $\begin{array}{l}\text { Menjadi media } \\
\text { penghubung } \text { user } \\
\text { dengan suatu biro } \\
\text { psikolog }\end{array}$ \\
\hline & Media konseling online & $\begin{array}{l}\text { Menjadi pembelajar dari } \\
\text { kompetitor }\end{array}$ \\
\hline & $\begin{array}{l}\text { Mengedukasi topik } \\
\text { kesehatan mental }\end{array}$ & \\
\hline & $\begin{array}{l}\text { Persuasi terhadap } \\
\text { kepedulian kesehatan } \\
\text { mental }\end{array}$ & \\
\hline & $\begin{array}{l}\text { Kompetitor : 1. Riliv } 2 . \\
\text { Pijar Psikologi 3. Get.Kalm }\end{array}$ & \\
\hline
\end{tabular}




\begin{tabular}{|c|l|l|}
\hline Kategori & \multicolumn{1}{|c|}{ Customer Market } & \multicolumn{1}{c|}{$\begin{array}{c}\text { Business \& } \\
\text { Organization Market }\end{array}$} \\
\hline \multirow{2}{*}{ Perbedaan } & $\begin{array}{l}\text { Konten yang ramah dan } \\
\text { sederhana }\end{array}$ & $\begin{array}{l}\text { Konsep TemanDengar } \\
\text { yang mudah dijangkau }\end{array}$ \\
\cline { 2 - 3 } & Enganging people & $\begin{array}{l}\text { Konsep alur cerita yang } \\
\text { akan dibawakan oleh } \\
\text { karakter }\end{array}$ \\
\hline
\end{tabular}

\begin{tabular}{|l|l|l|}
\hline Kategori & \multicolumn{1}{|c|}{ Customer Market } & \multicolumn{1}{|c|}{$\begin{array}{c}\text { Business \& } \\
\text { Organization Market }\end{array}$} \\
\hline & $\begin{array}{l}\text { Adanya TemanDengar } \\
\text { memberikan } \text { user } \\
\text { experience yang berbeda }\end{array}$ & $\begin{array}{l}\text { Adanya seminar membuat } \\
\text { kepercayaan } \text { user makin } \\
\text { tinggi }\end{array}$ \\
\hline
\end{tabular}

Sumber : Arsip TemanRindu 2020

Tabel 4. Lean Canvas TemanRindu

\begin{tabular}{|c|c|c|c|c|}
\hline \multirow{2}{*}{$\begin{array}{l}\text { Problem } \\
\text { - } \text { Batasan kode } \\
\text { etik saat } \\
\text { bercerita pada } \\
\text { TemanDengar } \\
\text { - } \text { Batasan } \\
\text { kemampuan tiap } \\
\text { TemanDengar } \\
\text { untuk menerima } \\
\text { cerita tiap } \\
\text { harinya } \\
\text { Cost, tidak } \\
\text { adanya investor } \\
\text { dan modal awal } \\
\text { membatasi } \\
\text { TemanRindu } \\
\text { untuk } \\
\text { menyediakan } \\
\text { fasilitas yang } \\
\text { cocok (Apps) }\end{array}$} & $\begin{array}{l}\text { Solution } \\
\text { - } \quad \text { Pembelajaran } \\
\text { berkelanjutan oleh } \\
\text { TemanDengar } \\
\text { - Scheduling bagi } \\
\text { TemanDengar } \\
\text { - Gencar selling } \\
\text { value-gain } \\
\text { investors }\end{array}$ & \multirow[t]{2}{*}{$\begin{array}{l}\text { Unique Value Proposition } \\
\text { - Konsep sederhana namun } \\
\text { efektif : "Hadir dan } \\
\text { Mendengar" } \\
\text { - Social media-based, } \\
\text { mudah dijangkau } \\
\text { - Terintegrasi, input cerita } \\
\text { dari user dapat dijadikan } \\
\text { konten (sesuai izin). Lalu } \\
\text { konten tersebut dapat } \\
\text { ditanggapi kembali oleh } \\
\text { user lain. }\end{array}$} & $\begin{array}{l}\text { Unfair Advantage } \\
\text { - Capable } \\
\text { Personnels, } \\
\text { TemanDengar } \\
\text { - Adanya ahli, } \\
\text { TemanPsikolog } \\
\text { - Pemasaran dan } \\
\text { konten yang } \\
\text { menyesuaikan } \\
\text { dengan tren }\end{array}$ & \multirow{2}{*}{$\begin{array}{l}\text { Customer Segments } \\
\text { - Primary User: } \\
\text { Orang yang } \\
\text { didiagnosa dan } \\
\text { yang memiliki } \\
\text { gejala kesehatan } \\
\text { mental } \\
\text { - Secondary User: } \\
\text { Orang yang } \\
\text { mawas atau } \\
\text { ingin belajar } \\
\text { tentang } \\
\text { kesehatan } \\
\text { mental dan } \\
\text { orang yang } \\
\text { membutuhkan } \\
\text { pendengar atas } \\
\text { ceritanya } \\
\text { Early Adopters: } \\
\text { Orang yang } \\
\text { penasaran } \\
\text { dengan apa yang } \\
\text { TemanRindu } \\
\text { lakukan }\end{array}$} \\
\hline & 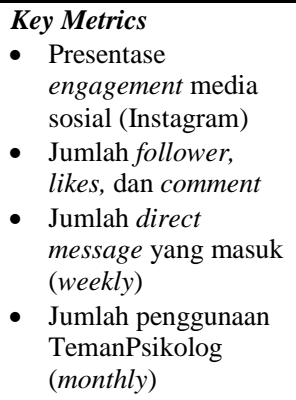 & & $\begin{array}{l}\text { Channels } \\
\text { - } \quad \text { Media Sosial } \\
\text { (Instagram dan } \\
\text { Twitter) } \\
\text { - Whatsapp } \\
\quad \text { (konseling) }\end{array}$ & \\
\hline \multicolumn{3}{|c|}{$\begin{array}{l}\text { Cost } \text { Structure } \\
\text { - } \quad \text { Production cost (meeting) } \\
\text { - } \quad \text { Marketing cost (instagram ads, paid promotion, premium tools) } \\
\text { - } \quad \text { Biaya pembicara dan akomodasi } \\
\text { - } \quad \text { Vendor EO \& venue }\end{array}$} & \multicolumn{2}{|c|}{$\begin{array}{l}\text { Revenue Streams } \\
\text { - Jasa dari fitur TemanPsikolog } \\
\text { - Paid content } \\
\text { - B2B dengan perusahaan lain } \\
\text { - Personal Funding }\end{array}$} \\
\hline
\end{tabular}

Sumber : Arsip TemanRindu 2020

TemanRindu memahami bahwa di masa yang semakin berkembang, masyarakat usia produktif adalah bagian yang vital dari potensi awal dari masalah kesehatan mental. Karena pada usia itulah frekuensi terjadinya interaksi satu sama lain sangat tinggi. TemanRindu menawarkan hal pembeda daripada platform konseling lainnya seperti aksesbilitas yang jauh lebih mudah dan pengemasan konten edukasi yang terkesan lebih ramah.

Target segmen konsumen untuk startup TemanRindu adalah anak muda usia produktif
(18-35 tahun), terlebih pemuda yang mencari konseling psikolog online. Karena cakupan segmen konsumen masih sangat luas, maka perlu dilakukan pengerucutan menjadi kelompok yang lebih kecil dan spesifik. Hal tersebut dilakukan agar pengembangan dan pemposisian produk lebih efektif. Segmen usia muda dapat dipecah menjadi segmen yang lebih kecil yaitu segmen late adolescence atau remaja akhir dan early adulthood atau dewasa muda. Selain menentukan segmen konsumen yang lebih kecil, perlu ditentukan early adopter atau 
kelompok konsumen yang berkemungkinan besar akan menggunakan layanan tersebut lebih awal atau sangat membutuhkan layanan tersebut. Early adopter dari TemanRindu adalah masyarakat yang mawas atau ingin belajar lebih lanjut mengenai kesehatan mental.

Hal tersebut sangat difokuskan dalam pelaksanaan kegiatan dengan tujuan meningkatkan kemawasan masyarakat terhadap kesehatan mental dalam rangka secara preventif menekan angka dampak.

Pada tahap selanjutnya adalah pembuatan prototipe. Mengingat kembali bahwa TemanRindu hadir sebagai media katarsis dan tempat konseling, hal tersebut dilandasi atas kepercayaan TemanRindu bahwa setiap orang berhak untuk menjadi sehat secara mental. Depresi adalah gangguan awal yang paling sering terjadi di dunia, hal tersebut cenderung didorong oleh perasaan kesepian dan tidak memiliki siapa pun. TemanRindu menghadirkan nilainya sebagai media katarsis, bahwa semua orang selalu memiliki teman untuk dibagikan cerita.

1. Verifikasi Hipotesis

2. Membuat MVP: Tujuan dan Jenis

TemanRindu memilih prototipe digital pada low fidelity MVP dan prototipe fisik pada high fidelity MVP. TemanRindu melakukan penyebaran MVP selama dua bulan dari bulan Maret 2020 hingga April 2020. Ekspektasi like yang diminta adalah $10 \%$ dari jumlah followers yang ada, comment berdasarkan $0,5 \%$ dari followers yang ada dan save adalah $0,2 \%$ dari followers yang ada. Gambar 5 dan Gambar 6 adalah contoh dari digital prototype yang diluncurkan TemanRindu selama masa rintisan. Dapat dilihat juga pada prototipe, TemanRindu mengutamakan kesesuaian desain dan keramahan warna tanpa mengurangi unsur materi yang diangkat.

\section{Gambar 5. Konten TemanRindu}

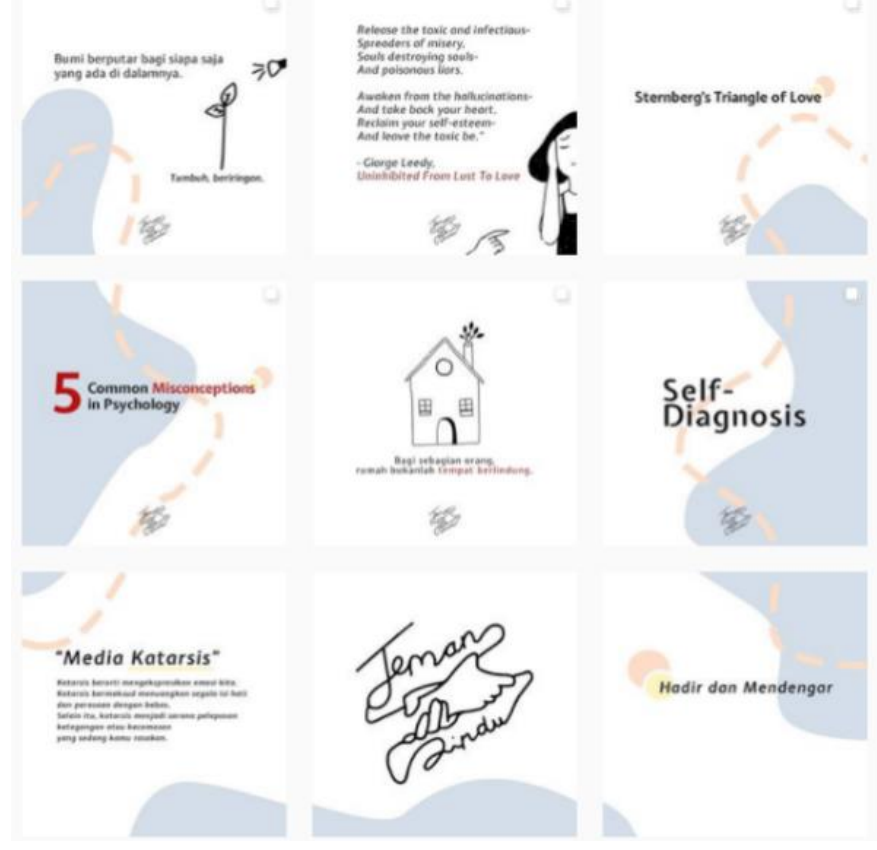

AdBispreneur : Jurnal Pemikiran dan Penelitian Administrasi Bisnis dan Kewirausahaan 


\section{Gambar 6.Tampilan Detail Konten \\ TemanRindu}

Release the toxic and infectious-

Spreaders of misery,

Souls destroying souls-

And poisonous liars.

Awaken from the hallucinations-

And take back your heart.

Reclaim your self-esteem-

And leave the toxic be."

- Giorge Leedy,

Uninhibited From Lust To Love
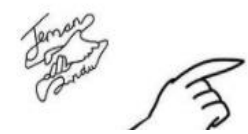

Tabel 5. Hasil Wawancara dan Feedback

\section{Pelanggan}

\begin{tabular}{|c|c|c|c|}
\hline Perbedaan & Sebelum & Masukan & Sesudah \\
\hline $\begin{array}{l}\text { Segmen } \\
\text { Konsumen }\end{array}$ & $\begin{array}{l}\text { Orang yang } \\
\text { memiliki } \\
\text { masalah pada } \\
\text { kesehatan } \\
\text { mental dan } \\
\text { pasar yang } \\
\text { berpotensi } \\
\text { memiliki } \\
\text { gangguan } \\
\text { kesehatan } \\
\text { mental }\end{array}$ & $\begin{array}{l}\text { Perlu } \\
\text { ditambah } \\
\text { segmentasi } \\
\text { untuk } \\
\text { pengguna } \\
\text { yang lebih } \\
\text { umum }\end{array}$ & $\begin{array}{l}\text { Orang yang } \\
\text { berpotensi serta } \\
\text { memiliki } \\
\text { gangguan } \\
\text { kesehatan mental } \\
\text { dan pengguna } \\
\text { umum yang } \\
\text { belum pernah } \\
\text { atau ingin belajar } \\
\text { psikologi. Usia } \\
\text { produktif (18-35 } \\
\text { tahun) }\end{array}$ \\
\hline Masalah & $\begin{array}{l}\text { Batasan } \\
\text { kemampuan } \\
\text { TemanDengar } \\
\text { untuk } \\
\text { menerima } \\
\text { cerita tiap } \\
\text { harinya }\end{array}$ & $\begin{array}{l}\text { Diadakan } \\
\text { penjadwalan } \\
\text { atau } \\
\text { penambahan } \\
\text { kuantitas }\end{array}$ & $\begin{array}{l}\text { Penambahan } \\
\text { kuantitas } \\
\text { personil } \\
\text { TemanDengar } \\
\text { dan shifting }\end{array}$ \\
\hline Solusi & $\begin{array}{l}\text { Pembelajaran } \\
\text { berkelanjutan } \\
\text { dan } \\
\text { penjadwalan } \\
\text { pada } \\
\text { TemanDengar }\end{array}$ & $\begin{array}{l}\text { Tidak ada } \\
\text { masukan }\end{array}$ & $\begin{array}{l}\text { Pembelajaran } \\
\text { berkelanjutan } \\
\text { dan penjadwalan } \\
\text { pada } \\
\text { TemanDengar }\end{array}$ \\
\hline Key Metrics & $\begin{array}{l}\text { Data-data } \\
\text { insight pada } \\
\text { konten } \\
\text { dijadikan tolak } \\
\text { ukur }\end{array}$ & $\begin{array}{l}\text { Tidak ada } \\
\text { masukan }\end{array}$ & $\begin{array}{l}\text { Data-data insight } \\
\text { pada konten } \\
\text { dijadikan tolak } \\
\text { ukur }\end{array}$ \\
\hline
\end{tabular}

\begin{tabular}{|c|c|c|c|}
\hline Perbedaan & Sebelum & Masukan & Sesudah \\
\hline $\begin{array}{l}\text { Unique Value } \\
\text { Proportion }\end{array}$ & $\begin{array}{l}\text { Social media- } \\
\text { based supaya } \\
\text { lebih mudah } \\
\text { untuk menjadi } \\
\text { terintegrasi } \\
\text { dari input } \\
\text { menjadi output } \\
\text { dan sebaliknya } \\
\text { (Lean) }\end{array}$ & $\begin{array}{l}\text { Penambahan } \\
\text { slogan }\end{array}$ & $\begin{array}{l}\text { Social media- } \\
\text { based } \text { supaya } \\
\text { lebih mudah } \\
\text { untuk menjadi } \\
\text { terintegrasi dari } \\
\text { input } \text { menjadi } \\
\text { output dan } \\
\text { sebaliknya } \\
\text { (Lean). Konsep } \\
\text { sederhana } \\
\text { namun efektif } \\
\text { untuk menjadi } \\
\text { slogan } \\
\end{array}$ \\
\hline $\begin{array}{c}\text { Unfair } \\
\text { Advantage }\end{array}$ & $\begin{array}{l}\text { Adanya } \\
\text { personil yang } \\
\text { berkapabilitas } \\
\text { dan memiliki } \\
\text { konsultan } \\
\text { seorang } \\
\text { psikolog }\end{array}$ & $\begin{array}{l}\text { Pengadaan } \\
\text { konsultan } \\
\text { bisnis } \\
\text { perusahaan }\end{array}$ & $\begin{array}{l}\text { Adanya personil } \\
\text { yang } \\
\text { berkapabilitas } \\
\text { dan memiliki } \\
\text { konsultan } \\
\text { seorang psikolog } \\
\text { dan konsultan } \\
\text { bidang bisnis } \\
\end{array}$ \\
\hline Channels & $\begin{array}{l}\text { Media sosial } \\
\text { (Instagram dan } \\
\text { Twitter) dan } \\
\text { Whatsapp } \\
\text { (konseling) }\end{array}$ & $\begin{array}{l}\text { Mencari } \\
\text { platform } \\
\text { yang lebih } \\
\text { privat } \text { untuk } \\
\text { konseling }\end{array}$ & $\begin{array}{l}\text { Media sosial } \\
\text { (Instagram dan } \\
\text { Twitter) dan } \\
\text { Web Room Chat } \\
\text { (konseling) }\end{array}$ \\
\hline $\begin{array}{c}\text { Cost } \\
\text { Structure }\end{array}$ & $\begin{array}{l}\text { Production } \\
\text { cost dan } \\
\text { marketing cost }\end{array}$ & $\begin{array}{l}\text { Tidak ada } \\
\text { masukan }\end{array}$ & $\begin{array}{l}\text { Production cost } \\
\text { dan marketing } \\
\text { cost }\end{array}$ \\
\hline $\begin{array}{l}\text { Revenue } \\
\text { Streams }\end{array}$ & $\begin{array}{l}\text { Jasa dari fitur } \\
\text { TemanPsikolo } \\
\text { g dan } B 2 B \\
\text { perusahaan } \\
\text { lain }\end{array}$ & $\begin{array}{l}\text { Saran } \\
\text { mencari } \\
\text { investor atau } \\
\text { inkubator }\end{array}$ & $\begin{array}{l}\text { Jasa dari fitur } \\
\text { TemanPsikolog, } \\
B 2 B \text { perusahaan } \\
\text { lain dan funding } \\
\text { dari investor }\end{array}$ \\
\hline
\end{tabular}

Sumber : Arsip TemanRindu 2020

Pada peluncuran MVP dengan bisnis model yang pertama, yaitu PsyWeek dan PsyFact, ditemukan followers tidak terlalu meningkat dikarenakan kecenderungan orang yang memilih untuk mempercayai informasi dari sumber yang terpercaya atau orang yang ahli pada bidangnya, juga orang lebih menyukai konten yang dikemas dengan ringan dan segar, maka dari itu perlu dilakukan evaluasi dari bentuk konten yang disuguhkan. Selain itu, para narasumber yang dipilih TemanRindu adalah orang yang ahli dalam suatu bidang, dalam hal ini adalah ahli pengembangan bisnis dan seorang psikolog. Setelah melakukan wawancara dengan para ahli dan mendapat timbal balik dari para followers, maka dibuatlah revisi MVP dengan berdasarkan perbaikan dari beberapa variabel dari model bisnis. 
Setelah dilakukan revisi, kemudian dilakukan penyebaran konten selama tiga bulan. Didapatkan peningkatan followers, like, share dan save yang drastis melebihi dari ekspektasi yang ada yaitu pada angka $20 \%$.

3. Membuat Slogan Posisi yang Kuat

\section{Gambar 7. Competition Map berdasarkan market effort dan value delivery}

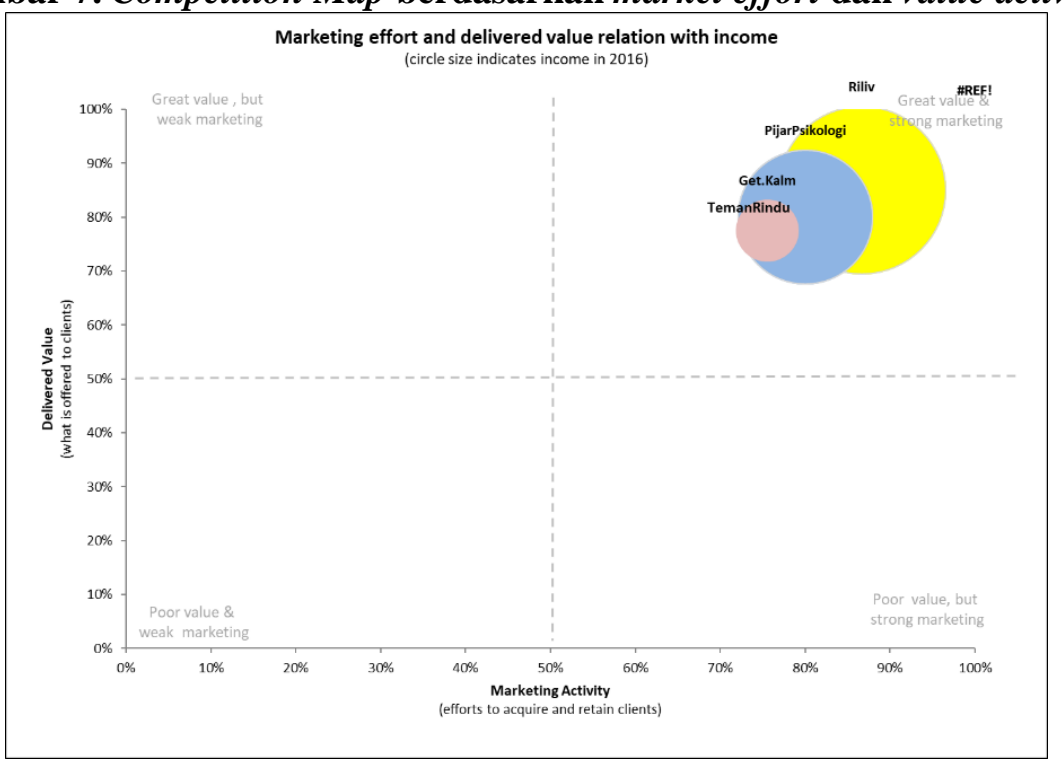

Sumber : Arsip TemanRindu 2020

Sesuai Competition Map yang didapatkan dari akumulasi poin value relation delivery komparatif dengan kompetitor seperti yang ditunjukkan pada Gambar 7. Metode perhitungan untuk mendapatkan peta kompetisi diambil dari metode yang diciptakan oleh Jonatan Donikas, mempertimbangkan aspekaspek yang sudah disediakan dan diisi secara subyektif berlandaskan survei kecil terhadap produk kompetitor. TemanRindu membuat slogan posisi dengan mendefinisikan target segmen berdasarkan empat kompetitor nasional dengan pengikut terbanyak, yaitu GetKalm, Pijar Psikologi dan Riliv.

Kemudian TemanRindu menentukan slogan posisi dengan mengisi poin kriteria secara subyektif tim dari beberapa usulan slogan yang sudah disepakati seperti pada Tabel 6.

Tabel 6. Nilai Slogan Usulan

\begin{tabular}{|c|l|c|c|c|}
\hline No. & \multicolumn{1}{|c|}{ Kriteria } & $\begin{array}{c}\text { Hadir dan } \\
\text { Mendengar }\end{array}$ & $\begin{array}{c}\text { Ada Untuk } \\
\text { Mendengar }\end{array}$ & $\begin{array}{c}\text { Mendengarkanmu, } \\
\text { kapanpun dan dimana pun }\end{array}$ \\
\hline 1 & $\begin{array}{l}\text { Apakah ini membedakan } \\
\text { produk dari alternatif } \\
\text { lain? }\end{array}$ & 10 & 6 & 8 \\
\hline 2 & $\begin{array}{l}\text { Apakah ini digunakan } \\
\text { untuk menyasar target } \\
\text { utama? }\end{array}$ & 10 & 7 & 8 \\
\hline 3 & $\begin{array}{l}\text { Apakah ini } \\
\text { mengidentifikasi nilai } \\
\text { tama dari produk? ini }\end{array}$ & 10 & 8 & 8 \\
\hline 4 & $\begin{array}{l}\text { Apakah brand } \\
\text { menjajikan? }\end{array}$ & 7 & 7 & 7 \\
\hline 5 & $\begin{array}{l}\text { Apakah mudah } \\
\text { dimengerti dan diingat? }\end{array}$ & 10 & 6 & 6 \\
\hline 6 & $\begin{array}{l}\text { Apakah konsisten } \\
\text { mencangkup banyak area }\end{array}$ & 8 & & \\
\hline
\end{tabular}




\begin{tabular}{|c|c|c|c|c|}
\hline No. & Kriteria & $\begin{array}{l}\text { Hadir dan } \\
\text { Mendengar }\end{array}$ & $\begin{array}{l}\text { Ada Untuk } \\
\text { Mendengar }\end{array}$ & $\begin{array}{l}\text { Mendengarkanmu, } \\
\text { kapanpun dan dimana pun }\end{array}$ \\
\hline & bisnis? & & & \\
\hline 7 & $\begin{array}{lr}\text { Apakah susah } & \text { ditiru? } \\
\text { Bisakah } & \text { hanya } \\
\text { TemanRindu } & \text { yang } \\
\text { memilikinya? } & \\
\end{array}$ & 8 & 4 & 8 \\
\hline 8 & $\begin{array}{lrr}\text { Apakah ini } & \text { untuk } \\
\text { kesuksesan } & & \text { jangka } \\
\text { panjang? } & & \\
\end{array}$ & 9 & 5 & 7 \\
\hline 9 & $\begin{array}{l}\text { Apakah ini dapat } \\
\text { mengalahkan } \\
\text { kompetitor? }\end{array}$ & 8 & 4 & 8 \\
\hline 10 & $\begin{array}{l}\text { Apakah ini dapat } \\
\text { membantu marketing } \\
\text { lebih efektif? }\end{array}$ & 10 & 7 & 8 \\
\hline & Total Nilai & 93 & 61 & 77 \\
\hline
\end{tabular}

Sumber : Arsip TemanRindu 2020

Tabel 7. Rancangan Sales Pipeline dan

\section{Funnel}

\begin{tabular}{|ll|ll|}
\hline \multicolumn{2}{|c|}{ Sales Funnel } & \multicolumn{2}{|c|}{ Sales Pipeline } \\
\hline 1. & Awareness / & 1. & Pengunjung instagram \\
& Attraction & 2. & PsyWeek \\
2. & Interaction & 3. & Meet The Experts \\
3. & Interest & 4. & PsyFact \\
4. & Action / & 5. & Instagram followers \\
& Closing & 6. & Instagram likes dan share \\
& 7. & Direct Message \\
& 8. & TemanDengar \\
& 9. & TemanPsikolog \\
& 10. & Penjualan Produk \\
& 11. & User yang membayar \\
& 12. & User yang mengiklankan \\
& 13. & User yang memberikan \\
& & feedback \\
& & \\
&
\end{tabular}

Sumber : Arsip TemanRindu 2020

Berdasarkan data yang diolah, TemanRindu dapat memberikan nilai yang bagus dan pemasaran yang cukup kuat. TemanRindu membuat slogan dengan penilaian berdasarkan pendapat dari internal tim TemanRindu dan didapatkan slogan terpilih yaitu "Hadir dan Mendengar" yang berarti TemanRindu hadir di tengah masyarakat untuk mengingatkan pentingnya untuk tidak merasa sendiri dan selalu merasa mempunyai telinga untuk mendengar cerita.

4. Memeriksa Saluran Komunikasi dan Distribusi

Membuat rancangan penjualan melalui pipeline atau funnel. TemanRindu memiliki 1.423 followers hingga 10 Oktober 2020. Tiap harinya terdapat beragam pengikut baru. TemanRindu membuat sales funnel dan sales pipeline yang berisikan dari empat tahap yaitu attraction, interaction, interest dan closing. Ditemukan dari checkpoint, $90 \%$ dari pelanggan potensial akan mengikuti TemanRindu setelah mereka berbicara dengan CEO atau anggota TemanRindu, $10 \%$ pengguna baru yang mengunjungi halaman TemanRindu akan mengikuti TemanRindu.

Followers akan bertambah setelah dikeluarkan konten yang baru dan lebih dari $25 \%$ followers akan menyukai konten TemanRindu. Sekitar $80 \%$ pengguna akan merekomendasikan salah satu konten TemanRindu ke teman mereka dan ditemukan juga rata-rata pengunjung halaman per tujuh hari adalah 1500 orang.

\section{Gambar 8. Competition Map berdasarkan like}

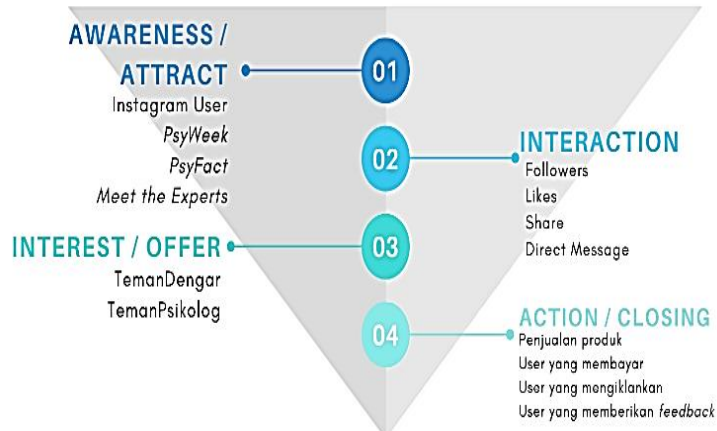

Sumber : Arsip TemanRindu 2020

Berdasarkan hasil penelitian yang dipaparkan, dilakukan analisis pada startup 
TemanRindu dan identifikasi risiko diterapkan pada Lean Canvas yang sudah dibuat. Ditemukan bahwa pengaplikasian metode Startup Evolution Curve memberikan hasil efektif pada pembuatan prototipe dan berdampak pada pertumbuhan bisnis jika dibandingkan dengan tanpa metode tersebut. Hal tersebut dikarenakan dalam Startup Evolution Curve, perusahaan diharuskan untuk membuat model bisnis. Pada penelitian ini model bisnis yang digunakan adalah Lean Canvas dengan pertimbangan bahwa blok-blok pada Lean Canvas memberikan kemudahan lebih pada perusahaan dalam mengidentifikasi keunggulan yang dimiliki, pengidentifikasian masalah serta solusi, penemuan saluran distribusi dan penentuan matrik pertumbuhan (Maurya, 2010). Berbeda dengan penelitian acuan sebelumnya dari Sharfina (2019), yang menggunakan perancangan prototipe dengan dasar model bisnis Business Model Canvas, yang hanya berfokus memberikan dasar pemikiran dari sebuah perusahaan. Hasil dari Lean Canvas yang dituang dalam bentuk prototipe produk terlihat lebih praktis dalam menemukan nilai lebih dari suatu perusahaan dan bagaimana cara memperkuatnya. Hal tersebut adalah pembeda sekaligus kontribusi dari penelitian ini.

Hasil analisis bagian paling riskan diambil dari tiga hal yaitu pertimbangan peneliti bersama konsultan perusahaan, hasil dari peluncuran prototype atau Minimum Viable Product (MVP) di Instagram serta timbal balik yang diberikan oleh para pelanggan. Dari ketiga hal tersebut dapat ditemukan bahwa bagian paling riskan adalah pada aspek produk yang ditawarkan juga bagaimana pengemasannya. Hal tersebut erat terkait dengan kebutuhan segmen konsumen, baik target utama, kedua maupun early adopter. Kejelasan dan spesifikasi dari produk harus detail agar mudah dipahami oleh calon pelanggan. Hal tersebut dapat diulas kembali dalam salah satu blok yang ada pada Lean Canvas yaitu Unique Value Proportion, yang memang berfungsi untuk menemukan nilai lebih yang dimiliki suatu perusahaan. Jika produk sudah sesuai dengan kebutuhan pasar, barulah dapat ditentukan strategi pemasaran dari tiap produknya supaya mendapat timbal balik yang memuaskan dari pelanggan dan menambah followers serta likes di instagram TemanRindu. Tentunya model bisnis harus selalu disesuaikan dengan keadaan atau pasar secara aktual (Jukka, et. al., 2018). Jika di kemudian hari konsumen TemanRindu bertambah sangat pesat, model bisnis harus segera merespon fenomena tersebut dan dilakukan penyesuaian kembali. Hal tersebut penting untuk dilakukan oleh tiap perusahaan startup untuk mengantisipasi keterbatasan ruang gerak dan kapasitas (Clayton, dkk., 2015).

Melalui pertimbangan kecenderungan pada tiap segmen, maka ditentukan model bisnis dengan produk yang dikemas secara segar, baru dan ringan supaya nilai dari produk tidak bias. Juga produk akan disertai dengan kontribusi dari para ahli di bidangnya dan orang-orang yang memiliki pengaruh besar sehingga nantinya dapat berpengaruh terhadap dampak kepada pasar.

Seluruh produk yang dibagikan di Instagram kemudian diberikan bingkai berupa konsep "Hadir dan Mendengar" yang berfokus pada maksud tujuan bahwa semua pengguna berhak untuk memiliki telinga untuk mendengar ceritanya. Tampilan user di laman instagram juga mengalami pengembangan, seperti ditambahkannya dua karakter ilustrasi bernama 'Fajar dan Sore' untuk membantu mengemas produk agar terkesan jauh lebih ramah daripada sebelumnya. Font-font yang digunakan dan peletakan materi juga diperhatikan oleh tim desain TemanRindu sendiri.

Setelah dilakukan penyesuaian terhadap kanvas sekaligus pada prototipe, TemanRindu melakukan peluncuran MVP kedua selama satu bulan pada bulan Juli 2020 hingga Agustus 2020. Kenaikan matriks seperti followers dan likes meningkat secara signifikan. Comments per unggahan juga mengalami kemajuan daripada sebelum dilakukan penyesuaian. Save di tiap unggahan jauh melebihi ekspektasi tim, serta penyesuaian yang dilakukan juga memicu kenaikan pengguna dalam menggunakan fitur dan produk TemanRindu.

\section{SIMPULAN}

Pengembangan bisnis pada startup TemanRindu menggunakan metode Startup Evolution Curve melalui tahapan kedua setelah 
startup melakukan tahap pertama secara mandiri. Tahapan tersebut adalah pembuatan Minimum Viable Product (MVP). Selama tujuh bulan penelitian, startup TemanRindu menghasilkan produk dan melakukan validasi dengan pengujian langsung ke pasar dalam tahapan pembuatan Minimum Viable Product (MVP).

Unique Value Proportion adalah bagian yang sangat penting karena bagian tersebutlah yang membedakan nilai suatu startup dengan startup lain. Unique Value Proportion yang dimiliki TemanRindu adalah hadir sebagai media katarsis pertama yang menawarkan jasa curhat dan konseling tanpa penggunaan yang rumit. TemanRindu juga hadir sebagai media edukasi psikologi yang dikemas dengan kemasan yang ringan dan ramah, dalam rangka tindakan preventif untuk menekan angka potensi gangguan mental. Selain dari Lean Canvas, jaringan bisnis yang dimiliki perusahaan, jalur rantai distribusi produk, strategi dalam perancangan produk, kekompakan dan kekuatan tim, dan cara pemasaran produk sebuah startup seperti pada tahap membuat saluran komunikasi dan distribusi serta competition map juga menjadi cara untuk unggul dalam persaingan dunia startup.

Penerapan metode Startup Evolution Curve pada startup TemanRindu sudah sangat tepat dan membantu dalam pengembangan bisnis dan produknya. Dalam metode tersebut, startup dituntun tahap demi tahap demi kepentingan perkembangan. Beberapa metode untuk startup awal lainnya seperti Business Model Canvas, Acquisition, Activation, Retention, Referral, Revenue (AARRR), Business Model Innovation, dll. cenderung lebih mudah diterapkan pada startup baru. Sedangkan TemanRindu adalah startup lama yang melakukan pivot dan ingin berfokus mengembangkan bisnis dengan output produk yang saling berintegrasi. Maka dari itu, startup TemanRindu sangat cocok dengan penerapan metode Startup Evolution Curve.

Penelitian ini hanya terbatas pada tahapan pembuatan Minimum Viable Product (MVP) dalam Startup Evolution Curve. Penelitian selanjutnya bisa mencangkup validasi dari semua blok pada kanvas yang dipakai supaya luaran model bisnis yang lebih sustain dan scalalable serta penelitian dengan menggunakan tahapan ketiga hingga kelima dari Startup Evolution Curve. Pada waktu selanjutnya, TemanRindu juga diharapkan untuk memperbanyak konten yang melibatkan ahli dan pihak luar karena pada survei kepuasan pelanggan memiliki angka yang baik pada konten tersebut. Hal itu juga akan berdampak pada branding perusahaan di mata masyarakat agar semakin mawas dan dikenal.

\section{DAFTAR PUSTAKA}

Maurya, A. (2010). Running Lean: Iterate From Plan A to A Plan That Works. Sebastopol: O' Reilly.

Atvoka, I., \& Ahokangas, P. (2020). From Structure to Process: Dynamic Aspects of Business Model Change. Journal of Business Models, 57-72.

Castro, F. G., Kellison, J. G., Boyd, S. J., \& Albert, K. (2010). Methodology for Conducting Integrative Mixed Methods Research and Data Analyses. Journal of Mixed Methods Research, 4(4), 342360. doi:10.1177/1558689810382916

Christensen, C. M., Raynor, M. E., \& Rory, M. (2015, December). What Is Disruptive Innovation? Retrieved from Harvard Business Review: https://hbr.org/2015/12/what-isdisruptive-innovation

Colis, D. (n.d.). Lean Strategy. Retrieved April 2020, from Harvard Business Review: https://hbr.org/2016/03/lean-strategy

Cuc, J. E. (2019). Trends in Business Model Research: A Bibliometric Analysis. Journal of Business Models, 1-24.

Escobar-Viera, C. G., Shensa, A., Bowman, N. D., Sidani, J. E., Knight, J., James, A. E., \& Primack, B. A. (2018). Passive and Active Social Media Use and Deppresive Symptoms Among United States Adults. Cyberpsychology, Behavior, and Social Networking.

Gordon, J. A. (2018, February). Depression. Retrieved from United States of America National Institute of Mental Health (NIMH USA): 
https://www.nimh.nih.gov/health/topics /depression/index.shtml

Hawari, D. (2005). Manajemen Stres Cemas dan

Depresi. Jakarta: Balai Penerbit FKUI.

Heikkilä, J., Heikkilä, M., Niemimaa, M., \& Järveläinen, J. (2018). Means to Survive Disruption: Business Model Innovation and Strategic Continuity Management? 31st Bled eConference: Digital Transformation.

Indarjo, S. (2009). Kesehatan Jiwa Remaja. Jurnal Kesehatan Masyarakat.

Indonesia, A. P. (2017). Hasil Survei Penetrasi dan Perilaku Pengguna Internet Indonesia 2017. Retrieved from APJII: https://www.apjii.or.id/content/read/39/ 342/Hasil-Survei-Penetrasi-danPerilaku-Pengguna-Internet-Indonesia2017

Johnson, R. B., Onwuegbuzie, A. J., \& Turner, L. A. (2007). Toward a Definition of Mixed Methods Research. Journal of Mixed Method Research.

Jonikas, D. (2017). Startup Evolution Curve From Idea to Profitable Business Idea (Vol. 1st Edition).

Krista Sorri, M. S. (2019). Business Model Innovation with Platform Canvas. Journal of Business Models, 1-13.

Marmer, M., Herrmann, B., Dogrultan, E., Berman, R., Eesley, C., \& Blank, S. (2011). Startup Genome Report Extra: Premature Scaling . Startup Genome.

Montemari, M., Chiucchi, M. S., \& Nielsen, C. (2020). Designing Performance Measurement Systems Using Business Models. Journal of Business Models, 48-69.

Osterwalder, A., \& Pigneur, Y. (2012). Business Model Generation. Jakarta: Kompas Gramedia.

Paternoster, N., Giardino, C., Unterkalmsteiner, M., Gorschek, T., \& Abrahamsson, P. (2014). Software Development in Startup Companies: A Systematic Mapping Study. Information and Software Technology.

Perkins, A. B., \& Perkins, M. C. (1999). The Internet Bubble. HarperBus.
Ries, E. (2011). The Lean Startup: How Today's Entrepreneur. New York: Crown Business.

Sharfina, N., Yuniaristanto, \& Zakaria, R. (2019). Business Development on Bukasuara Startup With Startup Evolution Curve Methods. Advances in Intellegent System Research.

Suryaningrum, S., \& Wardani, I. Y. (2013). Hubungan Antara Beban Keluarga Dengan Kemampuan Keluarga Merawat Pasien Perilaku Kekerasan di Poliklinik Rumah Sakit Marzoeki Mahdi Bogor. Jurnal Keperawatan Jiwa.

Taran, Y., Goduscheit, R. C., \& Boer, H. (2020). Business Model Inovation - A Gamble or a Manageable Proccess? Journal of Business Models, 90-107. 